\title{
Pengaruh Jumlah Sudu Impeller Terhadap Debit Air yang Dihasilkan Pompa Sentrifugal
}

\section{The Effect of The Number of Impeller Blades on The Water Flow Produced by The Centrifugal Pump}

\author{
Yakob Iskandar ${ }^{1}$, Nazaruddin Nazaruddin ${ }^{2 *}$, Zainal Arif ${ }^{3}$ \\ 1,2,3 Teknik Mesin Universitas Samudra
}

Diterima: 17-11-2020 ; Disetujui: 07-03-2021 ; Diterbitkan: 06-05-2021

*Corresponding author E-mail: nazaruddin@unsam.ac.id

\begin{abstract}
Abstrak
Abst Air digunakan dalam segala aspek kehidupan yaitu pertanian, perkebunan, perumahan, industri, pariwisata. Untuk mendapatan air diperlukan pompa. Pompa centrifugal adalah pompa yang sering digunakan. Kinerja pompa centrifugal dipengaruhi oleh disain impeller dan casing pompa. Disain sudu pompa akan menaikkan tekanan cairan dengan variasi kecepatan, gaya yang ditransformasikan ke impeller yang berputar dalam casing. Faktor yang sangat berpengaruh adalah desain impeller seperti jumlah sudu impeller. Tujuan penelitian ini adalah untuk mendapatkan debit air yang dihasilkan pompa centrifugal, untuk mendapatkan perbedaan debit air tertinggi, dan debit air terendah yang dihasilkan pompa centrifugal tipe shimizu PS 128 BIT, dengan variasi jumlah sudu impeller 21, 26, 31, 36, dan 41. Proses desain sudu impeller dalam penelitian ini menggunakan sofware autodesk fusion 360 dengan ukuran yang telah disesuaikan. Alat ukur digunakan dalam proses pengujian adalah flow meter, manometer, dan laser photo tachometer yang dirangkai pada pompa centrifugal. Putaran pompa saat pengujian adalah 2948 sampai 2959 Rpm. Hasil pengujian dengan menggunakan impeller jenis terbuka dan arah suction berada disamping impeller diperoleh kapasitas debit air tertinggi pada impeller dengan jumlah sudu 41 sebanyak 41,850 liter/menit. Kecepatan aliran air tertinggi yaitu 26,5 liter/menit pada diameter pipa 3/4 inci. Sedangkan tekanan air tertinggi pada impeller adalah $2,2 \mathrm{~kg} / \mathrm{cm}^{2}$.
\end{abstract}

Kata Kunci: kecepatan aliran air; pompa centrifugal; putaran pompa; tekanan air

\begin{abstract}
Water is used in all aspects of life, namely agriculture, plantation, housing, industry, tourism. To get water, a pump is needed. The centrifugal pump is a pump that is often used. Centrifugal pump performance is influenced by the design of the impeller and pump casing. The pump blade design will increase the liquid pressure at various speeds, the force is converted to a rotating impeller inside the casing. The most influential factor is the impeller design such as the number of impeller blades. The purpose of this study was to obtain the water flow produced by the centrifugal pump, to obtain the difference in the highest and lowest water flow rates produced by the shimizu PS 128 BIT type centrifugal pump, with variations in the number of impeller blades 21, 26, 31, 36, and 41. The design process of impeller blades in this study uses Autodesk Fusion 360 software with adjustable sizes. Measuring instruments used in the testing process are flow meters, manometers, and laser photo tachometers that are attached to centrifugal pumps. The pump speed when testing was 2,948 to 2,959 Rpm. The test results using an open type impeller and the direction of the suction beside the impeller, the highest water discharge capacity at the impeller is 41.850 liters / minute. The highest water flow rate is 26.5 liters / minute at a pipe diameter of 3/4 inch. Meanwhile, the highest water pressure on the impeller is $2.2 \mathrm{~kg} / \mathrm{cm}^{2}$.
\end{abstract}

Keywords: water flow velocity; centrifugal pump; pump rotation; water pressure 
How to Cite: Iskandar, Y., 2021, Pengaruh Jumlah Sudu Impeller Terhadap Debit Air yang Dihasilkan Pompa Sentrifugal, JMEMME (Journal of Mechanical Engineering, Manufactures, Materials and Energy), 5 (1): 78-90 


\section{PENDAHULUAN}

Air merupakan salah satu unsur alam yang sangat dibutuhkan dalam keberlangsungan kehidupan makhluk hidup khususnya manusia [1]. Dalam semua aspek kehidupan, air merupakan komponen yang mutlak harus tersedia baik sebagai komponen utama maupun sebagai komponen pendukung. Usaha pemenuhan kebutuhan air dalam kehidupan sehari-hari dapat dilakukan dengan memanfaatkan kondisi alam dan hukum dasar fisika ataupun dengan memanfaatkan peralatan mekanis hasil karya manusia [2].

Selain digunakan untuk keperluan minum dan rumah tangga, air juga dimanfaatkan dalam aspek kehidupan lainnya yaitu untuk pertanian, perkebunan, perumahan, industri, pariwisata [1]. Secara alamiah air akan mengalir dari tempat tinggi ke tempat rendah mengikuti gaya gravitasi bumi. Untuk aliran sebaliknya maka dibutuhkan peralatan yang dikenal dengan pompa [3].

Pompa merupakan suatu alat yang digunakan untuk mengubah energi mekanis menjadi energi hidrolis [4]. Pompa adalah alat yang digunakan untuk memindahkan cairan (fluida) dari suatu tempat ketempat yang lain, melalui media (saluran) dengan cara menambahkan energi pada cairan yang dipindahkan dan berlangsung kontinyu [5].

Pompa memiliki kegunaan yang sangat luas baik dikalangan rumah tangga ataupun skala industri. Desain sistem perpipaan menjadi sangat penting dan mempunyai efek yang sangat besar dalam kinerja pompa [6]. Pada umumnya, masyarakat sering menggunakan pompa yang diproduksi dari pabrik saja. Akan tetapi, masyarakat tidak terlampau mementingkan bentuk dan debit aliran air yang dihasilkan oleh pompa. Untuk itu perlu dilakukan penelitian lebih lanjut tentang karakteristik pompa, sistem kerja pompa terkhususnya tentang pengaruh impeller terhadap debit air dan kinerja pompa centrifugal [7].

Kinerja pompa ditentukan oleh head, kapasitas, dan efisiensi. Head adalah kemampuan dari pompa untuk mengangkut fluida, kapasitas adalah jumlah volume fluida yang berpindah atau dialirkan dalam satuan waktu, efisiensi adalah perbandingan daya pompa dibandingkan dengan energi yang dibutuhkan oleh motor penggerak mula untuk menjalankan pompa [5, 8, 9]. Banyak jenis pompa yang digunakan di masyarakat, namun jenis pompa centrifugal adalah jenis pompa yang sangat banyak dijumpai baik itu dikalangan industri maupun kalangan rumah tangga, baik itu skala kecil maupun skala besar [10] [11].

Pompa centrifugal adalah pompa yang mengubah energi kinetik impeller yang berputar menjadi energi tekan fluida. Prinsip kerjanya menaikkan tekanan cairan dengan memanipulasi kecepatan, gaya centrifugal dan mentransformasikan gaya tersebut ke impeller yang berputar di dalam casing untuk membuat perbedaan tekanan pada sisi hisap (suction) dan tekan (discharge) [12,13].

Pompa centrifugal sebagai salah satu jenis pompa yang banyak dijumpai di kalangan industri, pompa ini bekerja dengan putaran impeller sebagai elemen pemindah fluida yang digerakkan oleh suatu penggerak mula [14]. Zat cair yang berada didalam akan berputar yang disebabkan oleh dorongan sudu-sudu dan menimbulkan gaya centrifugal yang menyebabkan cairan mengalir dari tengah impeller dan keluar melalui saluran 
diantara susu-sudu dan meninggalkan impeller dengan kecepatan tinggi [4]. Pompa centrifugal adalah termasuk ke dalam jenis pompa tekanan dinamis [15].

Kinerja pompa sentrifugal pada dasarnya dipengaruhi oleh desain impeller dan rumah pompa. Banyak faktor yang berpengaruh terhadap desain impeller seperti sudut masuk dan sudut keluar impeller serta jumlah sudu dari impeller. Meskipun berbagai penelitian dan eksperimen tentang pompa sentrifugal telah dilakukan pada masa lalu, penelitian terhadap pengaruh bentuk geometri impeller belum dilakukan secara tuntas [16]. Berdasarkan fakta tersebut maka perlu dilakukan pengujian-pengujian eksperimental mengenai unjuk kerja pompa centrifugal, dengan menggunakan variabel penelitian jumlah sudu impeller pada pompa sentrifugal diharapkan memberikan perubahan kinerja pada pompa, juga dapat mempengaruhi debit air yang dihasilkan.

Firdaus Menyatakan bahwa variasi jumlah sudu impeler menyebabkan kecepatan akan berubah [17]. Variasi penggunaan impeler pompa mengakibatkan perubahan tekanan aliran disisi isap pompa dan sisi keluar pompa. Penurunan tekanan dibawah tekanan uap jenuh air sebagai penyebab utama terbentuknya gelembung uap. Perubahan tekanan yang mendadak disertai tingginya kecepatan fluida yang tidak merata pada sudu - sudu akan mengakibatkan intensitas getaran pada pompa dan munculnya suara bising.

Secara teoritis, dengan semakin bertambahnya jumlah sudu maka kerugian gesek yang terjadi akan lebih besar dan akan mempengaruhi performa pompa secara keseluruhan, namun hasil penelitian menyatakan lain $[18,19]$. Hal ini dikarenakan pada impeler dengan jumlah sedikit menyebabkan daerah laluan fluida menjadi besar. Hal ini memperbesar adanya aliran balik dari fluida kerja sehingga head yang dihasilkan akan turun. Selain itu lebarnya daerah laluan fluida juga akan semakin membuka peluang terjadinya tabrakan antar partikel fluida dan separasi aliran di tekanan yang dihasilkan di dalam rumah pompa yang pada akhirnya akan menyebabkan terjadinya penurunan kapasitas.

Pengaruh penambahan sudu impeler, meningkatkan tekanan sehingga head pompa sentrifugal pada aliran gas-cair juga mengalami peningkatan. Penurunan tegangan permukaan cairan mempermudah masuknya fasa gas ke dalam cairan, sehingga pemisahan antara fasa gas-cair di dalam impeler berkurang, tekanan dan debit pompa sentrifugal mengalami kenaikan [20].

Dari penelitian yang dilakukan oleh Erik Wahkidur Rohman dan Indra Herlamba Siregar didapatkan nilai head tertinggi dari desain impeller berupa torque flow impeller adalah 19.178meter dengan jumlah sudu 6. Dan kapasitas tertinggi didapatkan pada impeller dengan jumlah sudu 6 dengan nilai kapasitas yaitu 35.923liter/menit. Sedangkan efisiensi tertinggi didapatkan pada desain jumlah sudu 6 dengan nilai $42.053 \%$ pada putaran $2.700 \mathrm{rpm}$ [5]. Dari penelitian tersebut dimana menggunakan impeller jenis setengah terbuka dan arah suction pompa berada di depan impeller.

Untuk itu perlu dilakukan penelitian yang berbeda yaitu penelitian impeller jenis terbuka, dan arah discharge pompa berada di samping impeller. Dikarenakan jenis pompa ini sangat banyak digunakan khususnya di kalangan rumah tangga. Untuk kegunaan pompa jenis ini yaitu mengangkut air dari sumur yang dangkal dan industri kecil. 
Mengatasi permasalahan di atas, dikarenakan permintaan dan penggunaan pompa centrifugal jenis sumur dangkal dikalangan rumah tangga sangat tinggi. Untuk itu perlu dirancang dan dikembangkan mengenai pengaruh jumlah sudu impeller pada pompa centrifugal. Dari hal tersebut, penulis ingin mengetahui perbedaan debit air pada pompa centrifugal dengan memvariasikan jumlah sudu impeller. Adapun variasi jumlah sudu yang akan dirancang yaitu 21, 26, 31, 36, dan 41 sudu.

Adapun tujuan penelitian ini adalah: 1). Untuk mendapatkan debit air tertinggi dan debit air terendah yang dihasilkan pompa sentrifugal tipe Shimizu PS 128 BIT dengan memvariasikan jumlah sudu impeller. 2). Untuk mendapatkan fenomena serta perubahan yang terjadi pada RPM pompa dengan beban yang dihasilkan impeller. 3). Untuk mengetahui kelebihan dan kekurangan impeller.

\section{METODE PENELITIAN}

Alat-alat yang dibutuhkan dalam penelitian ini yaitu alat-alat produksi yang digunakan pada pembuatan impeller pompa centrifugal dalam penelitian ini yaitu mesin bubut, mesin bor, mesin gerinda, kertas pasir, kunci ring dan kunci pas, LPG 3 kg, tabung oksigen, obeng, martil, mesin las, tang, flow meter, laser tacho fhotometer, dan manometer.

Bahan-bahan yang digunakan dalam penelitian ini yaitu aluminium bekas, pasir silika, air, gas LPG, oksigen, dan elektroda.

Adapun skema pelaksanaan (tahapan penelitian) diantaranya yaitu:

1. Melakukan desain jumlah sudu impeller dengan menggunakan sofware.

2. Pembuatan tungku untuk peleburan aluminium impeller.

3. Pembuatan cetakan berbahan pasir untuk mencetak impeller.

4. Melakukan pembubutan impeller yang sudah dicetak pada cetakan pasir.

5. $\quad$ Proses pembuatan sudu impeller dengan menggunakan gerinda.

6. Melakukan tahapan pengujian dari setiap jumlah sudu impeller.

Adapun jenis pompa sentrifugal yang digunakan dalam penelitian ini adalah jenis pompa shimizu PS-128 BIT. Shimizu PS-128 BIT merupakan pompa air sumur dangkal berdaya listrik 125 watt.

\section{HASIL DAN PEMBAHASAN}

Setelah desain gambar selesai, selanjutnya dilakukan pembuatan impeller dengan prosedur yang telah ditentukan. Adapun impeller yang telah dibuat yaitu impeller 21 sudu, 26 sudu, 31 sudu, 36 sudu, dan 41 sudu. 


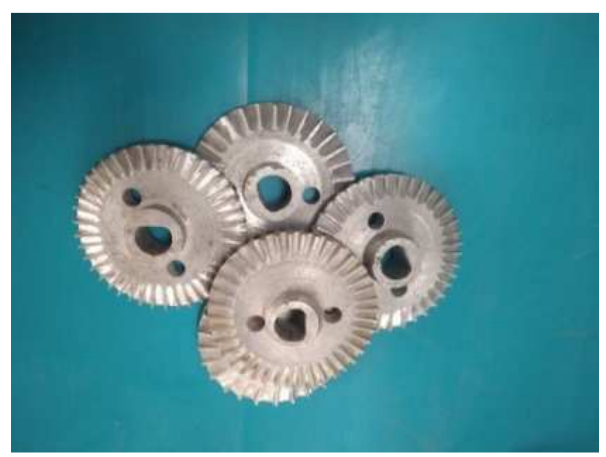

Gambar 1. Hasil Pembuatan Impeller

Pengukuran berat maupun bobot dari setiap impeller yang telah dibuat pada penelitian ini dilakukan dengan menggunakan timbangan digital. Selanjutnya untuk hasil pengukuran dari setiap impeller dapat dilihat pada tabel 1.

\begin{tabular}{ccc}
\multicolumn{3}{c}{ Tabel 1. Pengukuran Berat Impeller } \\
\hline No. & $\begin{array}{c}\text { Jumlah Sudu } \\
\text { (n) }\end{array}$ & $\begin{array}{c}\text { Berat } \\
\text { Impeller } \\
\text { (gram) }\end{array}$ \\
\hline 1. & 21 & 38 \\
2. & 26 & 36 \\
3. & 31 & 35 \\
4. & 36 & 36 \\
5. & 41 & 37 \\
\hline
\end{tabular}

Setelah selesai pembuatan ke-5 (lima) impeller dengan variasi jumlah sudu yang berbeda. Kemudian dilakukan pengujian dari ke-5 impeller dengan melihat perbandingan debit air yang dihasilkan pompa centrifugal dari variasi jumlah sudu yang berbeda.

Setelah bahan dan alat telah disediakan, kemudian rangkai pompa sedemikian rupa agar dapat dilakukan pengujian. Metode pengujian pada penelitian ini yaitu dengan memasukkan air bersih sebanyak 200liter ke dalam tong penampungan. Pengujian impeller dilakukan secara bertahap dimulai dari pengujian impeller 21, 26, 31, 36, dan 41 sudu. Adapun pengujian terebut dilakukan dengan durasi waktu yang telah ditentukan untuk setiap pengujian yaitu: 1 menit, 1,5 menit, 2 menit, 2,5 menit, dan 3 menit yang diukur menggunakan alat ukur stopwatch.

Tabel 2. Pengukuran Berat Impeller

\begin{tabular}{cccccc}
\hline $\begin{array}{c}\text { Jumlah } \\
\text { Sudu } \\
(\mathrm{n})\end{array}$ & $\begin{array}{c}\text { Waktu (t) } \\
(\mathrm{ml})\end{array}$ & $\begin{array}{c}1,5 \\
(\mathrm{ml})\end{array}$ & $\begin{array}{c}2 \\
(\mathrm{ml})\end{array}$ & $\begin{array}{c}2,5 \\
(\mathrm{ml})\end{array}$ & $\begin{array}{c}3 \\
(\mathrm{ml})\end{array}$ \\
\hline 21 & 25.0 & 48.0 & 68.0 & 89.0 & 100.5 \\
26 & 36.0 & 60.0 & 72.2 & 96.0 & 108.5 \\
31 & 37.0 & 61.0 & 74.0 & 98.0 & 122.0 \\
36 & 38.0 & 61.5 & 76.0 & 100.0 & 125.0 \\
41 & 40.0 & 64.5 & 80.0 & 104.0 & 130.0 \\
\hline
\end{tabular}


Pada pengujian impeller ini yaitu untuk mendapatkan debit air yang dihasilkan oleh pompa centrifugal. Cara pengujian ini dilakukan dengan menghidupkan pompa secara bersamaan menggunakan stopwatch dengan durasi waktu yang telah ditentukan yaitu 1 menit, 1,5 menit, 2 menit, 2,5 menit, dan 3 menit. Kemudian hasil air yang diperoleh dilakukan pengukuran menggunakan beaker glass.

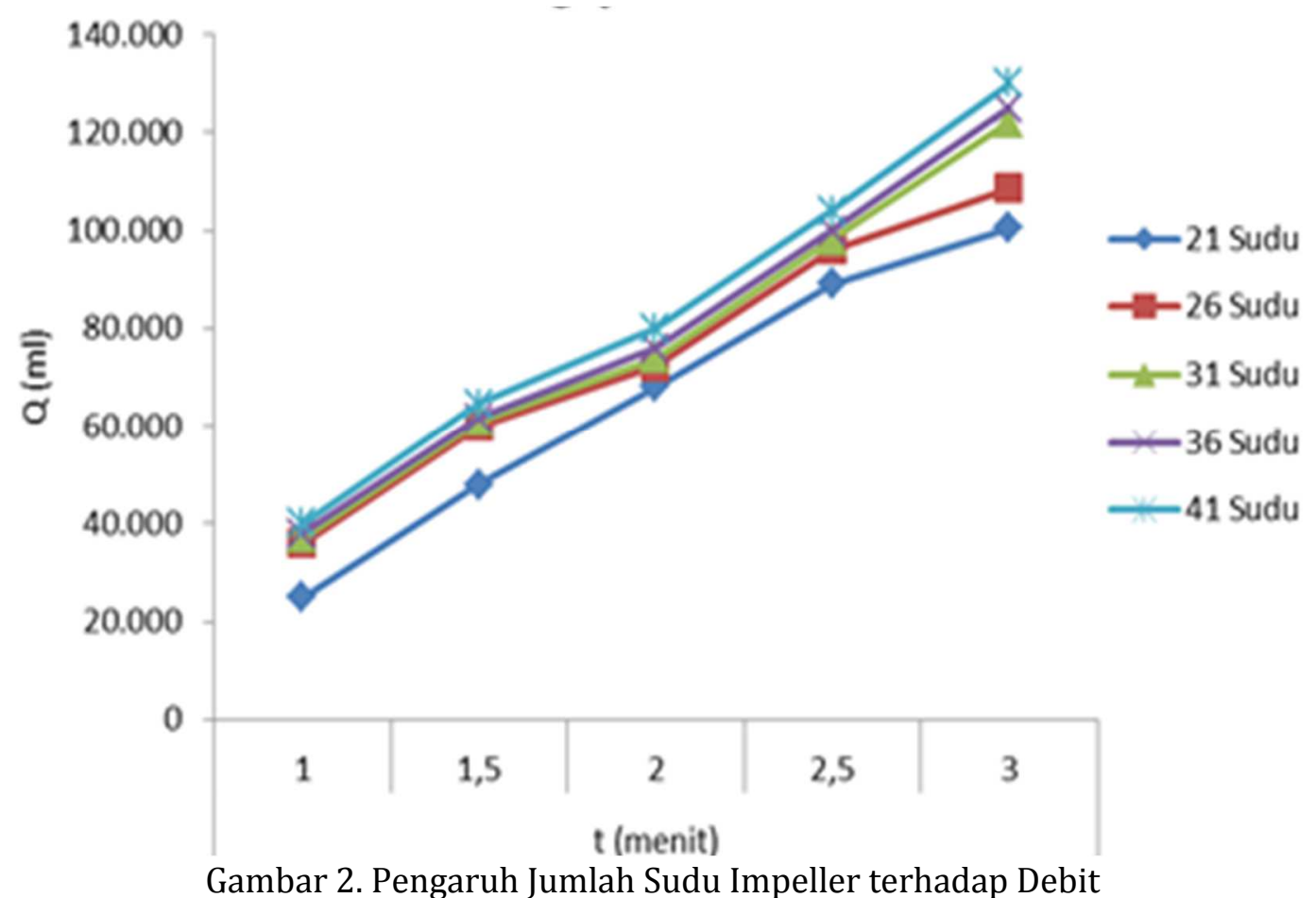

Dari grafik pada Gambar 2 dapat dijelaskan bahwa jumlah sudu pada setiap impeller sangat berpengaruh terhadap debit air yang dihasilkan pompa centrifugal dengan varian waktu yang berbeda. Semakin besar jumlah sudu impeller maka semakin besar pula debit air yang dihasilkan oleh pompa. Pada penelitian ini yang telah dilaksanakan dan dituangkan ke dalam grafik pada gambar 2 sudah dilakukan 5 (lima) variasi waktu yang berbeda. Hal tersebut menunjukkan bahwa jumlah sudu 21 memperoleh debit air terendah sedangkan jumlah sudu 41 memperoleh debit air tertinggi. Dimana dalam waktu 1 menit impeller 41 sudu menghasilkan debit air sebanyak 40.000 ml sedangkan pada impeller 21 sudu menghasilkan debit air sebanyak $25.000 \mathrm{ml}$. Dari hasil data tersebut didapatkan perbedaan jumlah debit air dalam durasi waktu 1 menit hingga $15.000 \mathrm{ml}$ atau sebanding dengan 15 liter.

Untuk dapat melihat perbandingan debit air yang dihasilkan dari setiap impeller maka pada penelitian ini seluruh variasi waktu 1 menit, 1,5 menit, 2 menit, 2,5 menit, dan 3 menit dijumlahkan. Sehingga diperoleh total durasi waktu pompa menyala selama 10 menit. Untuk lebih jelasnya total debit air yang dihasilkan pompa centrifugal dalam total waktu 10 menit dalam keadaan pompa tanpa berhenti dapat dilihat pada tabel 3. 
Tabel 3. Perbandingan Debit Air yang Dihasilkan dari Setiap Impeller Jumlah Sudu Debit Air Durasi 10 Menit

(n) $\mathrm{ml}$

\begin{tabular}{ll}
\hline 21 & 330,500 \\
26 & 372,700 \\
31 & 393,000 \\
36 & 399,500 \\
41 & 418,500 \\
\hline
\end{tabular}

Dari hasil data yang didapat pada tabel 3 sehingga dapat dituangkan dalam grafik pada gambar 3 yang dimana impeller 21 sudu menghasilkan debit air terendah yaitu sebanyak $330.500 \mathrm{ml}$ dalam waktu 10 menit atau dapat dirata-ratakan 33,5 L/menit $\left(\mathrm{m}^{3} /\right.$ menit). Sedangkan impeller 41 sudu menghasilkan debit air tertinggi yaitu sebanyak $418.500 \mathrm{ml}$ dalam waktu 10 menit atau dapat dirata-ratakan 33,5 L/menit ( $\mathrm{m}^{3} / \mathrm{menit}$.

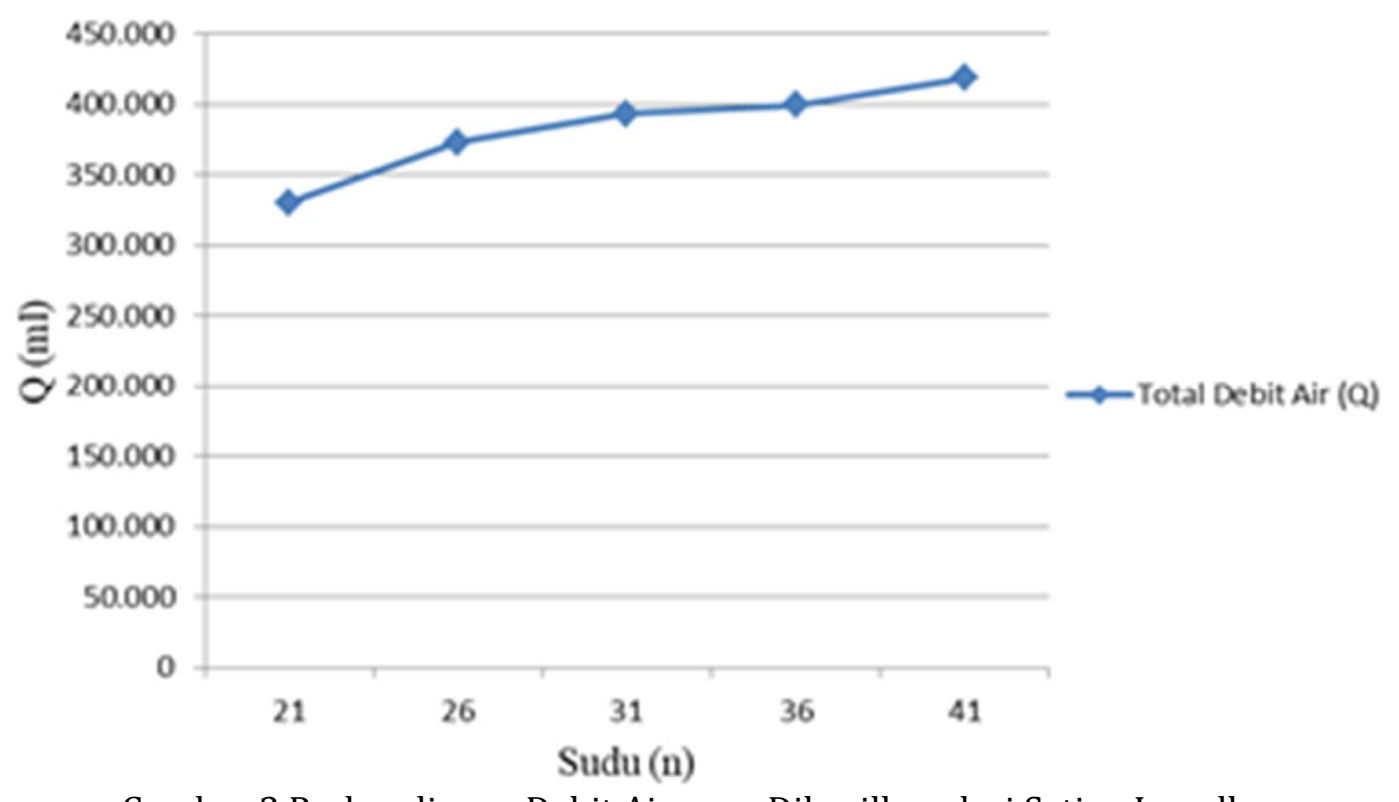

Gambar 3 Perbandingan Debit Air yang Dihasilkan dari Setiap Impeller

Dalam grafik pada gambar 3 juga menunjukkan bahwa impeller $26 \mathrm{sudu}, 31 \mathrm{sudu}$, 36 sudu, dan 41 sudu menghasilkan peningkatan debit air yang signifikan sedangkan impeller 21 sudu menghasilkan penurunan debit air yang sangat drastis. Penurunannya dapat dikatakan sangat tidak wajar dikarenakan mencapai $42.200 \mathrm{ml}$ jika dibandingkan dengan penurunan impeller yang lain hanya mencapai $19.000 \mathrm{ml}$.

Dalam penelitian ini bukan hanya melihat debit air yang dihasilkan pompa, akan tetapi sangat penting juga untuk menganalisa tekanan air yang dihasilkan oleh pompa pada setiap impeller yang berbeda. Dimana alat ukur yang digunakan untuk mengukur tekanan air tersebut yaitu manometer yang sudah dirangkai dengan pipa 3/4 inci. Data hasil pengukuran tekanan air diperlihatkan pada Tabel 4. 
Yakob Iskandar, Pengaruh Jumlah Sudu Impeller Terhadap Debit Air ...

Tabel 4. Hasil tekanan air

\begin{tabular}{cc}
\hline $\begin{array}{c}\text { Jumlah Sudu } \\
\text { (n) }\end{array}$ & $\begin{array}{c}\text { Tekanan Air (P) } \\
\mathrm{kg} / \mathrm{cm}^{2}\end{array}$ \\
\hline 21 & 1 \\
26 & 1,5 \\
31 & 1,7 \\
36 & 1,9 \\
41 & 2,2 \\
\hline
\end{tabular}

Grafik pada Gambar 4 menunjukkan bahwa semakin banyak jumlah sudu impeller maka semakin besar juga tekanan yang dihasilkan. dimana dapat dilihat bahwa impeller 21 sudu menghasilkan tekanan air yang lebih rendah yaitu hanya didapat $1 \mathrm{~kg} / \mathrm{cm}^{2}$. Sedangkan impeller 41 sudu menghasilkan tekanan air yang lebih tinggi yaitu mencapai $2,2 \mathrm{~kg} / \mathrm{cm}^{2}$.

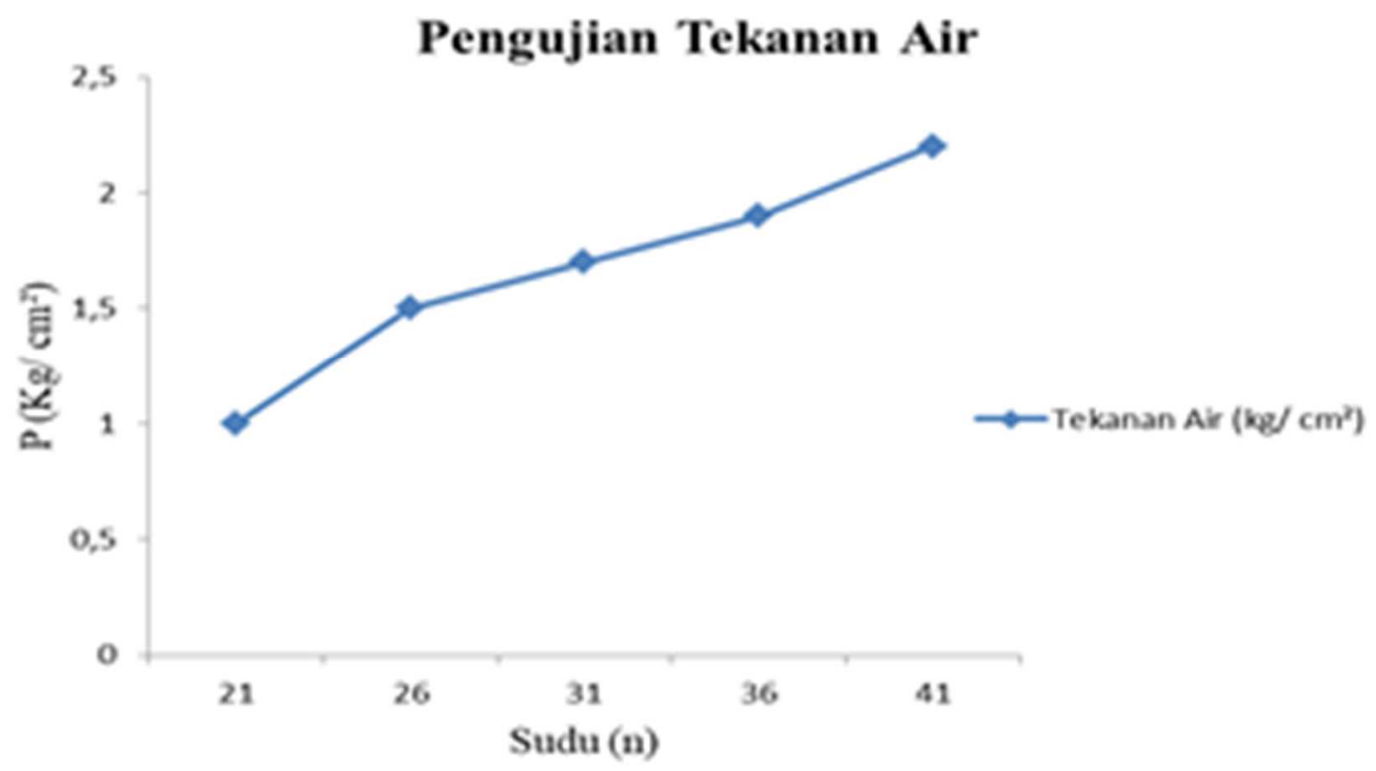

Gambar 4 Pengaruh Tekanan Air terhadap Variasi Jumlah Sudu Impeller

Pada penelitian ini juga diukur dan dianalisa kecepatan aliran fluida. Dimana cara pengujian yang dilakukan yaitu dengan menggunakan alat flow meter yang telah dipasangkan pada rangkaian pompa. Setelah alat tersebut sudah terpasang dengan rangkaian pompa maka dilakukan pengukuran dari setiap pengujian impeller.

Untuk pengukuran dan pengambilan data yang dilakukan secara bersamaan dengan pengambilan data debit aliran air. Hasil pengukuran yang didapat dari setiap pengujian impeller dapat dilihat pada tabel 6 . 
Tabel 6 Pengaruh Kecepatan Aliran Fluida terhadap Variasi sudu Jumlah Impeller

\begin{tabular}{cc}
\hline $\begin{array}{c}\text { Jumlah } \\
\text { Sudu (n) }\end{array}$ & $\begin{array}{c}\text { Kecepatan Aliran (v) } \\
\text { liter/ menit }\end{array}$ \\
\hline 21 & 22,5 \\
26 & 23,5 \\
31 & 24,5 \\
36 & 25,5 \\
41 & 26,5 \\
\hline
\end{tabular}

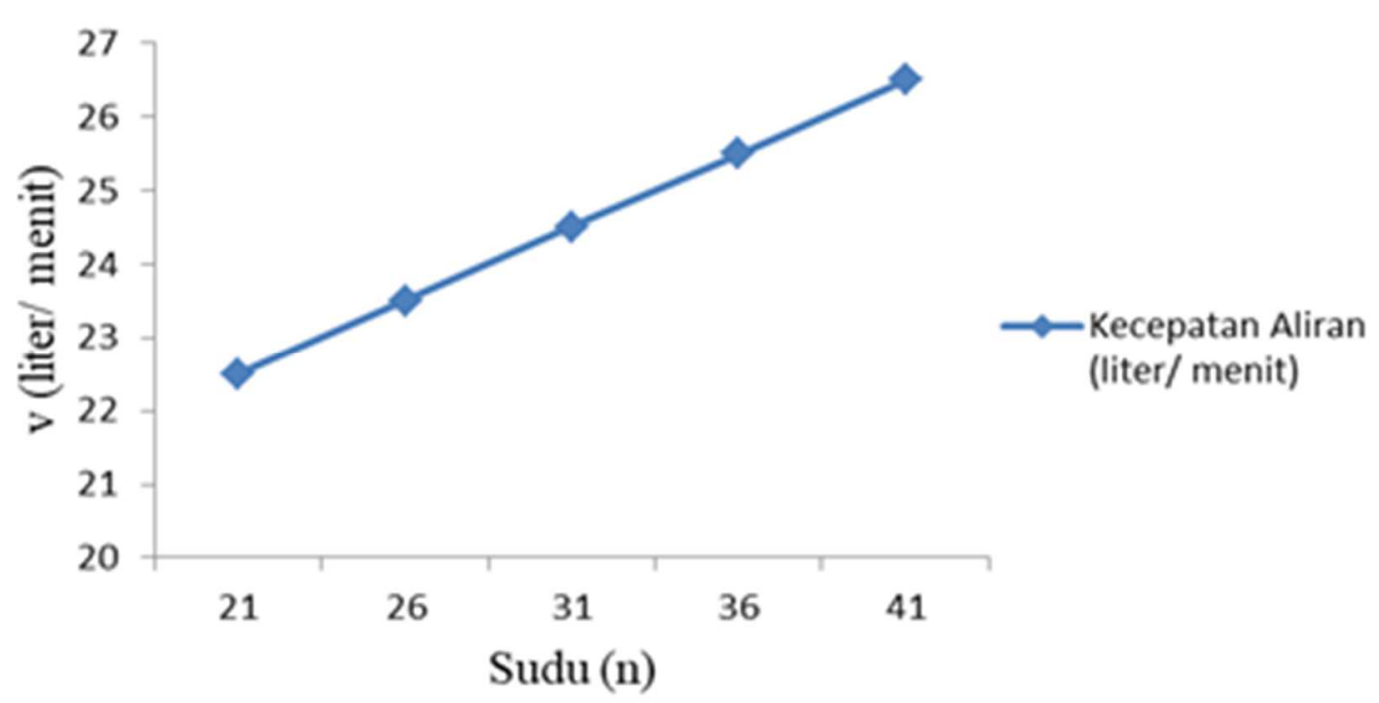

Gambar 5. Pengaruh Kecepatan Aliran Fluida (liter/ menit) terhadap Variasi Jumlah Impeller

Berdasarkan data pengukuran kecepatan aliran dari pengujian setiap impeller dapat dituangkan dalam bentuk grafik yang ditunjukkan pada gambar 5. Dari grafik dapat dijelaskan bahwa kecepatan aliran yang dihasilkan pompa mulai dari 21 sudu, 26 sudu, 31 sudu, 36 sudu, dan 41 sudu dapat terbilang peningkatan kecepatan aliran fluida sangat stabil. Dari grafik tersebut juga dapat dijelaskan bahwa semakin besar jumlah sudu impeller maka semakin besar pula kecepatan aliran fluida yang dihasilkan.

Dari data pengukuran kecepatan aliran dari pengujian setiap impeller dapat dituangkan dalam bentuk grafik yang ditunjukkan pada gambar 5. Dari grafik dapat dijelaskan bahwa kecepatan aliran yang dihasilkan pompa mulai dari 21 sudu, 26 sudu, 31 sudu, 36 sudu, dan 41 sudu dapat terbilang peningkatan kecepatan aliran fluida sangat stabil. Dari grafik tersebut juga dapat dijelaskan bahwa semakin besar jumlah sudu impeller maka semakin besar pula kecepatan aliran fluida yang dihasilkan. Hasil Pengukuran RPM Pompa terhadap Variasi Jumlah Sudu Impeller diperlihatkan pada tabel 7. 
Yakob Iskandar, Pengaruh Jumlah Sudu Impeller Terhadap Debit Air ...

Tabel 7. Hasil Pengukuran RPM Pompa terhadap Variasi Jumlah Sudu Impeller

\begin{tabular}{cccccc}
\hline $\begin{array}{c}\text { Waktu } \\
\text { (t) }\end{array}$ & $\Omega$ Sudu & $\Omega$ Sudu & Rpm Pompa & & \\
menit & 21 & 26 & 31 & 36 & 41 \\
\hline 1 & 2955 & 2954 & 2955 & 2951 & 2950 \\
1,5 & 2955 & 2954 & 2953 & 2952 & 2951 \\
2 & 2956 & 2955 & 2952 & 2951 & 2948 \\
2,5 & 2959 & 2958 & 2954 & 2952 & 2951 \\
3 & 2957 & 2956 & 2955 & 2953 & 2952 \\
\hline
\end{tabular}

Dari pengambilan data kecepatan sudut pada penelitian ini dapat dituangkan ke dalam bentuk grafik, untuk lebih jelasnya dapat dilihat pada Gambar 6.

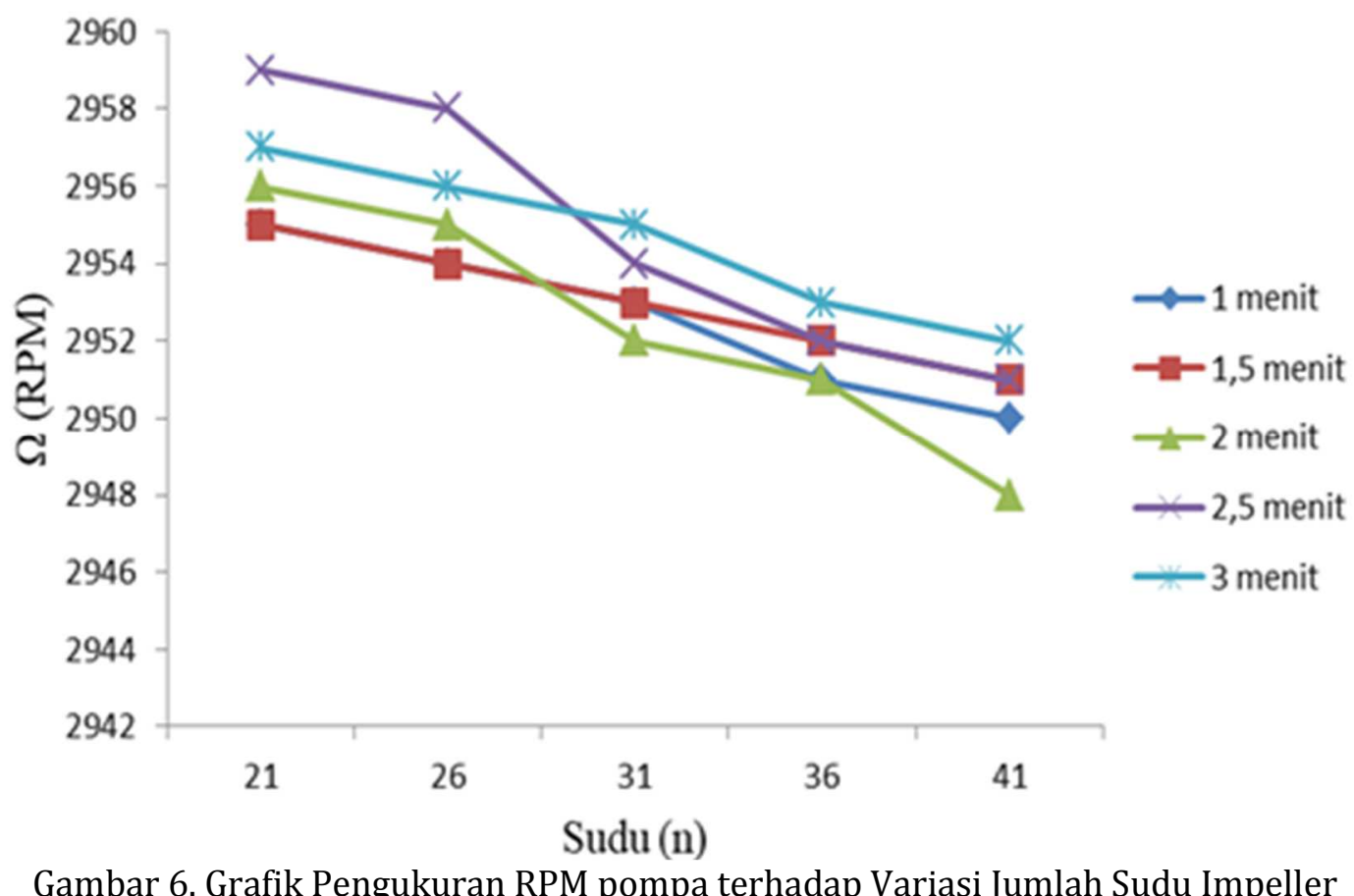

Berdasarkan grafik hasil tersebut dapat dijelaskan bahwa semakin besar jumlah sudu impeller maka semakin rendah pula kecepatan sudut pompa, sebaliknya semakin kecil jumlah sudu impeller maka semakin tinggi kecepatan sudut yang dihasilkan atau semakin besar debit air yang dihasilkan pompa, maka semakin rendah rpm pompa tersebut begitu juga sebaliknya. Jadi, dapat disimpulkan debit air juga sangat mempengaruhi kecepatan putaran motor listrik.

\section{KESIMPULAN}

Dengan mengacu terhadap penelitian yang telah dilakukan, diperoleh hasil pengujian pompa sentrifugal dengan memvariasi jumlah sudu impeller 21, 26, 31, 36, dan 41 didapatkan debit air tertinggi pada impeller dengan jumlah sudu 41 yaitu sebanyak 
41,85 L/menit ( $\mathrm{m}^{3} /$ menit), sedangakan Impeller 21 sudu menghasilkan debit air terendah yaitu sebanyak 33,5 L/menit $\left(\mathrm{m}^{3} /\right.$ menit. Jika beban yang dihasilkan pompa semakin tinggi maka RPM (daya pompa) semakin rendah, sebaliknya jika beban yang dihasilkan pompa semakin rendah maka RPM (daya pompa) akan semakin tinggi. Oleh karena itu, jika pompa bekerja secara terus-menerus dengan beban yang terlalu berat maka akan membuat pompa mudah panas sehingga stator dan gulungan dinamo pompa menjadi rusak. Jika jumlah sudu impeller lebih dari 41 sudu maka jarak antara sudu yang satu dengan sudu yang lain tidak ada lagi yaitu kurang dari $3 \mathrm{~mm}$, jika jarak terlalu sempit maka tidak ada celah air masuk sehingga impeller tidak dapat lagi untuk mengangkut air. Sedangkan jika jumlah sudu kurang dari 21 sudu maka tekanan air menjadi tidak ada ataupun tekanan air kurang dari $1 \mathrm{~kg} / \mathrm{cm}^{2}$, jika tekanan air tidak ada di khawatirkan air tidak akan dapat naik disebabkan sulit melakukan vakum dan jika air dapat naik namun debit air akan sangat sedikit.

\section{REFERENSI}

[1] D. N. Admadhani, A. H. S. Hajil and L. D. Susanawati, "Analysis of Water Supply and WaterDemand for Carrying Capacity Assessment (Case Study of Malang)," Sumber daya alam dan Lingkungan, p. 13-20, 2013.

[2] N. Nasruddin and Z. Arif, "Analisa Perubahan Temperatur dan Kelembaban Relatif pada Inkubator Penetas Telur yang Menggunakan Fan dan Tidak Menggunakan Fan," Umum Teknik Terapan, vol. 1, no. 1, p. 31-35, 2014.

[3] P. Gunawan, Rancang Bangun Alat Peraga Sistem Pompa Sentrifugal, Jakarta: Teknik Mesin Universitas Islam Indonesia, 2018.

[4] M. Muhtadin, Perawatan Korektif Pompa Sentrifugal Between Bearing (3003 J) Di Pt. Pupuk Kujang Cikampek, Bandung: Unpas Press, 2017.

[5] E. W. ROHMAN, "UJI EKSPERIMEN PENGARUH JUMLAH SUDU TORQUE FLOW IMPELLER TERHADAP KINERJA POMPA SENTRIFUGAL," Jurnal Teknik Mesin, vol. 3, no. 3, pp. 145-151, 2015.

[6] I. Febrianto, M. Kabib and B. S. Nugraha, "PERANCANGAN SISTEM POMPA PARALEL DENGAN DAYA BERVARIASI UNTUK MENINGKATKAN KAPASITAS AIR," Jurnal CRANKSHAFT, vol. 1, no. 1, pp. 49-54, 2018.

[7] N. Nasruddin, Z. Arif and T. A. Rizal, "Kajian Numerik Perbaikan Desain Pada Arah Aliran Jet Pump," Jurnal Umum Teknologi Terapan, vol. 1, no. 1, p. 18-26, 2014.

[8] A. J. Zulfikar, "The Flexural Strength of Artificial Laminate Composite Boards made from Banana Stems," Budapest International Research in Exact Sciences (BirEx) Journal, vol. 2, no. 3, pp. 334-340, 2020.

[9] M. Y. Yuhazri, A. J. Zulfikar and A. Ginting, "Fiber Reinforced Polymer Composite as a Strengthening of Concrete Structures: A Review," in 2nd International Conference in Industry and Manufacture Engineerin, Medan, 2020.

[10] F. R. SAKHTY, STUDI EKSPERIMEN PERBANDINGAN UNJUK KERJA POMPA SHIMIZU PS-116 BIT STANDAR DAN MODIFIKASI DENGAN METODE PENGUJIAN, Surabaya: ITS Press, 2016.

[11] A. A. M, "PENGARUH JUMLAH SUDU SENTRIFUGAL IMPELLER TERHADAP KAPASITAS DAN EFISIENSI POMPA SENTRIFUGAL," Jurnal Teknik Mesin, vol. 3, no. 3, pp. 136-144, 2015.

[12] I. H. Siregar , "ENERGI KONSERVASI PADA POMPA SENTRIFUGAL DENGAN TORQUE FLOW IMPELLER SEMI OPEN DAN CLOSED PADA PENGATURAN KAPASITAS," Otopro, vol. 15, no. 2, pp. 54-58, 2020. 
[13] A. J. Zulfikar, A. Sofyan and M. Y. Siahaan, "Numerical Simulation on The Onion Dryer Frame Capacity of 5 kg/hour," JMEMME (Journal of Mechanical Engineering Manufactures Materials and Energy), vol. 2, no. 2, p. 86-92, 2018.

[14] S. Hariady, "Analisa Kerusakan Pompa Sentrifugal 53-101C WTU Sungai Gerong PT. Pertamina RU III Plaju," Jurnal Desiminasi Teknologi, vol. 2, no. 1, pp. 29-42, 2014.

[15] A. Aziz, R. Meimaharani and M. I. Ghozali, "SISTEM INFORMASI GEOGRAFIS BANGUNAN CAGAR BUDAYA DI KABUPATEN KUDUS BERBASIS WEB," in SNATIF, Kudus, 2016.

[16] A. Riyanto, Analisa Pengaruh Jumlah Sudu Impeler Terhadap Getaran pada Pompa Sentrifugal, Surakarta: UMS Press, 2013.

[17] M. Mustakim, "PENGARUH KECEPATAN SUDUT TERHADAP EFISIENSI POMPA SENTRIFUGAL JENIS TUNGGAL," Turbo, vol. 4, no. 2, pp. 79-83, 2015.

[18] W. Wardjito, "PERENCANAAN INSTALASI POMPA RETURN PUMP DENGAN KAPASITAS 130 M3/JAM UNTUK EXCHANGER HEATER AMONIA," Wahana Teknik, vol. 1, no. 1, pp. 53-64, 2012.

[19] A. Rahmansyah and A. J. Zulfikar, "Manufacture of Water Pipe From Clampshell Powder Materials," JMEMME (Journal of Mechanical Engineering Manufactures Materials and Energy), vol. 2, no. 2, pp. 73-77, 2018.

[20] W. D. Putro, "Pengujian Kinerja Pompa Sentrifugal Menggunakan Kontrol Inventer," SEMESTA TEKNIKA, vol. 13, no. 1, pp. 21-30, 2010. 